\title{
Factors That Affect Taxpayers' Adoption for Electronic Tax Service: The Case of Addis Ababa Taxpayers
}

\author{
Nesredin Mekonnen \\ MSc. In Accounting and finance, Department of Accounting and Finance, Woldia University, Woldia, Ethiopia
}

\begin{abstract}
Electronic tax service is one of the most useful instruments to increase revenue of government and taxpayers. However, only small numbers of taxpayers are using the service and others found to be reluctant to use electronic tax service. Therefore, the study was focused on factors that affect taxpayers' adoption for electronic tax service in Addis Ababa. Two-stage sampling was employed to select sample respondents. Descriptive statistics and probit regression analysis were employed. The result shows that perceived usefulness, perceived risk, self-efficiency and timeliness were significant factors but, subjective norm is insignificant. Tax authorities should do on expanding the electronic tax service to other branches.
\end{abstract}

Keywords: Electronic Tax Service, Adopter, Non-Adopter, Addis Ababa

DOI: $10.7176 /$ RJFA/11-21-02

Publication date: November $30^{\text {th }} 2020$

\section{Introduction}

Considering globalization without information technology and communication is meaningless, because globalization and technology advancement are directly or indirectly connected with information technology. Globalization and technology advancements are highly confronting the way business organizations are conducted their activity and competition coupled with customer demands has driven the use of technology. Rapid changes in the field of information technology have created an array of business opportunities rather than challenges. It is noting that one of the opportunities is electronic tax service (Johnson, 2009).

The electronic government has designed a process in which information and services are electronically delivered to customers including businesses, citizens and governmental agencies (Irani et al., 2008). The revolution has resulted in significant evolutions in manners of providing services not only for taxpayers, but also for citizens as a whole and businesses organizations. Governments around the world have planned a simple project which is electronic government with the aim of delivering services through electronic system since information technology has failed to achieve its proper place in terms of functioning effectively in organizations and governmental agencies (Torres et al., 2005). Electronic government refers to provision of online public service to citizens and businesses organizations. It is way of providing service in fast, less cost, proper and easy (Teodora, 2008).

Electronic tax service is a specific implementation of electronic government and it refers to transorganizational processes with data transfer between the information technology systems of the professionals and those of the tax authorities (Trauner, 2005). The benefits from the use of the electronic tax service are various like enjoying cost-free preparation and report of tax returns, safety, security, all-time availability and time saving, as most people can do their online tax return in a short time, and no location problems since returns can be completed on any computer (Davis, 1989).

The aim of this paper is to examine factors affecting taxpayers' adoption for e-tax service in Ethiopia revenue and custom authority in Addis Ababa large taxpayers, west and east branches. Several factors that affect taxpayers' adoption for electronic tax service have been identified in literatures including Perceived usefulness (Shidaei \& Shahrokh, 2012), subjective norms and perceived risk (Hung et al., 2006). However, most of the previous researches like (Wang, 2002),Hung et al. (2006), Fu et al., (2005), Anna et al. (2010), Amin (2008) and Shidaei \& shahrokh (2012)on adoption for electronic tax service have been conducted not in the context of Ethiopia tax system. Using additional explanatory variables, like self-efficiency and timeliness, this paper provides additional knowledge on the factors that affect adoption for electronic tax service in Ethiopia taxpayers' context.

\section{Literature Review}

Electronic tax service is a very specific form of electronic government that supports tax authority processes, work flow systems and electronic record management on the one hand, knowledge management and automated risk analysis to assess the credibility of tax returns on the other hand (Trauner , 2007). According to Naidoo (2007), conducted an empirical study on taxpayers adoption of electronic tax payment and the study adopted the technology acceptance model. The study is aimed to determine factors that influence the acceptance of an electronic tax service. It revealed that perceived usefulness was highly significant independent variable in influencing adoption of e-tax service. According to Hussein et al. (2010), on the title transforming government: electronic government application: an integrated model on adoption of online tax service the results had implied that perceived usefulness and perceived ease of use were significant variables and the public tend to evaluate the 
electronic tax service systems based on their ease of use and usefulness. According to Beneke et al. (2011), a research conducted on electronic service quality in South Africa, the study was revealed that timeliness in respect to timely responses and communication between taxpayers and company in an online system was fundamental for the effectiveness of adopting electronic tax service. According to Hung et al. (2006), on the title determinants of user acceptance of the electronic government services: The case of online tax filing and payment system, that subjective norm and self-efficiency are significant for non-adopters, but the two variables are insignificant for adopters. The adopters of electronic tax service may not consider subjective norms an issue of particular importance. A research performed on the adoption of electronic tax filing systems: an empirical study, its results support that a significant effect of self-efficacy on behavioral intention through perceived usefulness and perceived credibility. This article has indicated that users who have higher self-efficacy are likely to have more positive usefulness and ease of use beliefs (Wang, 2002).

According to Hung et al. (2006), they stated that perceived risk is significantly influence adopters' attitudes toward the electronic tax service. However, perceived risk is not significant for non-adopters. They believed that lower risk level should be beneficial determinants for electronic tax services adopters; as for non-adopters, possible reasons are that perceived risk not easily perceived or that little weight is assigned to them. In another study conducted on the acceptance of electronic tax filing: a study of taxpayer intentions they have found that in spite of the adopters of e-tax service have perceived higher risk than non-adopter, but perceived risk is not significant to influences taxpayers' choice of tax filing method (Fu et al., 2005). According to Tella \& Olasina (2014), they employed the technology acceptance model to predict the users' intentions to continue using electronic payment system. A simple random sampling technique was used to select respondents. The results revealed that there is correlation among perceived usefulness and attitude to use, perceived usefulness and continuance intention to use. Anna et al. (2010), a study examining on the factors, which influence the adoption of electronic tax returns, among taxpayers using technology acceptance model, perceived usefulness and perceived risk, are important factors for the effect which taxpayers' perceptions have on electronic filing of taxation system. According to Amin (2008),conducted a study on factors affecting the intentions of customers to use mobile phone credit cards and the result revealed that perceived usefulness is significantly affected customer intention to use mobile phone credit cards. According to Shidaei \& shahrokh (2012), on the title factor affecting the acceptance of the electronic system to receive tax returns using planned behavior theory, results showed that perceived usefulness is statistically significant and affect taxpayers' acceptance.

As tax is the main source of government revenue and government needs to collect sufficient revenue, it requires modernizing way of collection by introducing electronic tax service. In this study I believed that the study fills some gaps by providing information which is supported by evidence in the area of factors affecting taxpayers' adoption for electronic tax service for the coming researchers and current policy recommendations. In addition fill the literature gap and addresses the issue in-depth by combining additional explanatory variables and by using cross-sectional methodology.

\subsection{Methodology and Data}

This paper is interested in examining the effect of the in dependent variables (self-efficiency, usefulness, perceived risk, subjective norm and timeliness) on the dependent variable (adoption of electronic tax service). Therefore, quantitative approach is more appropriate to achieve the purpose of this study, since this paper is searching for what factors affect adoption of electronic tax service, because of the fact that those variables can be easily quantified. In general, results are interpreted in quantitative component. In this study, the researcher uses two stage sampling procedure for the selection of sample respondents. In the first stage, out of 19 Ethiopia revenue and custom authority branches in Addis Ababa three branches namely large taxpayers, west and east branches will be purposively selected based on the basis of their e-tax service accessibility and availability of information. In the second stage, first the taxpayers in the three sample branches identified and stratified in to two strata: e-tax user and non-user. The non-users are selected within branches of e-tax service users to ensure homogeneity of factors. Ethiopia Revenue and Custom Authority (ERCA) Addis Ababa large taxpayers, west and east branches have total taxpayers of 18,030. This study used Cochrane sample size formula (1975) and select total sample of 284 taxpayers, 33 from e-tax service adopters and 251 taxpayers from non-adopters were drawn by taking in to account probability proportional to sample size, since the numbers of taxpayers in the three branches are not proportional. The research uses cross sectional data from Ethiopia revenue and custom authority in the year of 2018 through primary data collection and analyzed both in descriptive and statistical methods.

\subsection{Econometric Model specification}

Electronic tax service is a dependent variable, which is dichotomous taking on two values, one if the taxpayer adopts e-tax service and zero otherwise. Estimation of this type of relationship requires the use of quantitative response models. In this regard, the non-linear probability models, logit and probit models are the possible alternatives. However, several estimation problems arise particularly when Ordinary Least Squares regression and 
linear probability models are employed (Gujarati, 2004). The probit probability model is associated with the cumulative normal probability function, whereas, the logit model assumes cumulative logistic probability distribution are very close to each other, except at the tails, not likely to get very different results using the logit or the probit model. Therefore, given the similarity between the two models, it is possible to use probit model for the analysis of factors that affect adoption for electronic tax service.

To conduct the research I have used Technology Acceptance Model (TAM) which is an information systems theory that how users come to accept and use a technology. Broadly, technology acceptance model indicates the intensity of an individual's intention to use a technology can be explained jointly by his or her perception about the technology's usefulness and attitude towards the technology ease of use (Chau\& Hu, 2001). According to Davis (1989), this model suggests that when users are presented with a new technology, a number of factors influence their decision about how and when they will use it (Perceived usefulness and Perceived ease-of-use). This study have used perceived usefulness from technology acceptance model and four additional variables are included in this study to provide better understanding on taxpayers' adoption of e-tax service. The four variables that included are subjective norms, self-efficacy, perceived risk and timeliness. To conduct this study, the dependent variable which is adoption for e-tax service (AETS) depending on 5 independent variables which are: self-efficiency of taxpayers, perceived usefulness, perceived risk, subjective norm and timeliness. In order to fulfill the desired objectives the following functional form is used.

$\mathrm{Pi}=\mathrm{f}(\mathrm{Z1}, \mathrm{Z2}, \mathrm{Z3}, \mathrm{Z} 4 \ldots . . \mathrm{Zn})$

The econometric equation for the probit model stated in equation (1) can be specified as:

$\mathrm{Pi}=\alpha \mathrm{o}+\alpha 1 \mathrm{Z} 1+\alpha 2 \mathrm{Z} 2+\alpha 3 \mathrm{Z} 3 \ldots \ldots+\alpha \mathrm{nZn}+\mu \mathrm{i}$

Where, $\mathrm{Pi}=$ dichotomous variable representing adoption for electronic tax service; and it is equal to one if the taxpayer adopt e-tax service and zero otherwise. $\mathrm{Z1}, \mathrm{Z2}, \mathrm{Z3} \ldots . . \mathrm{Zn}$ is the vector of variables that affect adoption of e-tax service decision to use e-tax service. Parameters; $\alpha 1, \alpha 2, \alpha 3 \ldots \ldots$ anrepresents coefficients for the row vectors to be estimated, and $\mu \mathrm{i}$-is the error term.

\section{Result and Discussion}

This study employed the probit regression model to estimate and infer the parameters of the factors that affect taxpayers' adoption for electronic tax service. Out of the total five explanatory variables, output for the probit equation shows that four variables were found to be significantly affect the probability of adopting electronic tax service. Variables found to be significant included; perceived usefulness, perceived risk, self-efficiency and timeliness of e-tax service.

Perceived usefulness: In this study, perceived usefulness is the degree to which a taxpayer believes that using electronic tax service would increase his or her productivity or revenue. Empirically many studies have found significant relationship between perceived usefulness and taxpayers' adoption of e-tax service like (Davis et al., 1989; Pikkarainen et al., 2004: Amin et al., 2007; Amin, 2008 and Chung, 2008). Thus when taxpayers believe that electronic tax service is useful, they will adopt the system. This study found that perceived usefulness is an important variable in the regression analysis because it affects taxpayers' adoption for electronic tax service. Other variables remains constant, the discrete effect of a change from (0) to (1) in perceived usefulness increases the probability of taxpayers to adopt the service by 17.47 percent.

A study conducted on determinants of online tax payment system in Malaysia taxpayers' the regression result showed that perceived usefulness was significant at p-value of 0.004 (Suhani, 2010). The regression analysis result revealed that perceived usefulness is statistically significant at $1 \%$ level of significance. The positive association implies that when e-tax service is being useful, taxpayers intend to adopt it

Perceived risk: the taxpayer may unwilling to adopt the electronic tax service if they do not feel that the electronic tax service is free from risk (Hussein et al., 2010). Studies like Hung et al. (2006), assumed that perceived risk has significant effect on taxpayers' attitude to adopt or not to adopt the electronic tax service. In this study also perceived risk is significant explanatory variable that affect taxpayers adoption for e-tax service. Other variables remains constant a change from (0) to (1) in perceived risk decreases the probability of taxpayers to adopt the service by 15.66 percentage point. The probit regression result revealed that perceived risk is statistically significant at $1 \%$ level of significance. The negative association implies that when e-tax service is being risk, taxpayers do not intend to adopt it.

Subjective norms: It is believed to affect adoption of electronic tax service because taxpayers may affect by negative experience around them to perform service, even if they are not themselves favorable toward the consequences (Hussein et al., 2010). For the electronic tax service, those who are free from subjective norms to use electronic tax service would benefit from its productive in doing tax return online. The probit regression result for subjective norm revealed that $\mathrm{p}$-value of 0.710 which is insignificant. Thus subjective norm has no impact on taxpayers' adoption for e-tax service in the study area

Self-efficiency: In this paper, self-efficiency refers to ability of taxpayers to operate electronic tax service or the system. If they have ability to operate the system, they intend to adopt the electronic tax service unless they do not 
intend to adopt. A study conducted on determinants of online tax payment system in Malaysia taxpayers' the regression result revealed that perceived usefulness has significant effect on online tax payment system at $1 \%$ significant level (Suhani, 2010). The study revealed that, self-efficiency is statistically significant at $5 \%$ level of significance and the marginal effect reveals that those taxpayers who have ability to operate the electronic tax service have 9.74 percentage points more chance to adopt the e-tax service than those who have no ability to operate the system. While keeping all other variables constant at their value or the discrete effect of a change from 0 to 1 in self-efficiency increases the probability of taxpayers' adoption by 9.74 percentage points higher than their counterparts, holding other variables constant at their value.

Timeliness of e-tax service: readiness of electronic tax service for report and payment of tax while taxpayers needed the service intend taxpayers' to adopt the service. Timeliness in respect to timely responses and communication between taxpayers and the company in an online system are critical for adopting electronic tax service (Beneke et al, 2011). The study revealed that, timeliness is statistically significant at 5\% level of significance and the marginal effect reflected that, being timeliness of electronic tax service has 7.36 percentage probabilities to adopt the e-tax service. While keeping all other variables constant or the discrete effect of a change from 0 to 1 in timeliness, increases the probability of taxpayers' adoption by 7.36 percentage points holding other variables constant at their value. The marginal effect of the significant explanatory variables on adoption for electronic tax service is as follow.

Binary probit model and its marginal effect on the determinants of adoption for e-tax

\begin{tabular}{|l|l|l|l|l|}
\hline Variables & Std. err. & $\mathrm{Z}$ & $\mathrm{p}>|\mathrm{z}|$ & Marginal effect \\
\hline $\mathrm{Pu}$ & 0.04448 & 3.93 & $0.000^{* * *}$ & 0.1747499 \\
\hline $\mathrm{Pr}$ & 0.05577 & -2.81 & $0.005^{* * *}$ & 0.1566222 \\
\hline $\mathrm{Sn}$ & 0.02746 & 0.37 & 0.710 & 0.0102213 \\
\hline $\mathrm{Se}$ & 0.04249 & 2.29 & $0.022^{* *}$ & 0.0973823 \\
\hline $\mathrm{Tl}$ & 0.03410 & 2.16 & $0.031^{* *}$ & 0.0736737 \\
\hline Cons. & 0.52968913 & -4.85 & $0.000^{* * *}$ & - \\
\hline
\end{tabular}

Dependent variable adoption for electronic tax service

$\begin{array}{lc}\text { Log pseudo likelihood } & -51.970903 \\ \text { Wald chi2 (5) } & 43.32 \\ \text { Prob }>\mathrm{chi}^{2} & 0.0000 \\ \text { Pseudo R }{ }^{2} 0 . & 4288 \\ \text { Number of observations } & 208\end{array}$

Source: computed from own survey data, (2018)

$\mathrm{Dy} / \mathrm{dx}$ (marginal effect) is for discrete change of dummy variables from 0 to 1

Note: $* *$ and $* * *$ indicate significant at $5 \%$ and $1 \%$ level of significance respectively

\section{Conclusions and Recommendation}

\subsection{Conclusion}

The overall motive of this study was to evaluate the factors of taxpayers' adoption for electronic tax service in Ethiopia revenue and custom authority west, east and large Addis Ababa taxpayers. Data for the study were collected from randomly selected taxpayers using structured questionnaires schedule in three branches; west Addis Ababa, east Addis Ababa and Addis Ababa large taxpayers. Both Quantitative and qualitative data types related to factors of adoption for e-tax service were collected from primary sources through sample respondents and Secondary sources also used to enrich data from primary sources. Two types of respondents; electronic tax service adopters and non-adopters were considered for the study. The sample size is 284(33 e-tax service users and 251 non-users), but only 208 (33 user and 175 non-user) questionnaires were returned.

Probit regression model was employed to examine the factors that affect taxpayers' adoption for e-tax service. Chi-square test was applied to statistically compare adopters of e-tax service and non-adopters for discrete explanatory variables. From the estimation result of the marginal effect of the probit model for the factors of taxpayers' adoption for e-tax service four variables were found to be significant on the probability of adoption for e-tax service. The variables that become statistically significant include perceived usefulness, perceived risk, selfefficiency and timeliness.

Being usefulness of e-tax service creates higher probability for taxpayers to adopt the service. This indicates that when the e-tax service is useful as perceived, the probability of taxpayers to adopt it increases. Perceived risk also negatively and significantly associated with taxpayers' adoption for e-tax service. Furthermore, self-efficiency and timeliness affect taxpayers' adoption for electronic tax service positively and significantly. Self-efficient taxpayers to operate the system have higher probability to adopt the e-tax service than those who cannot able to operate the system. Timeline e-tax service also attracted taxpayers to adopt it and affect adoption for e-tax service positively. 


\subsection{Recommendation}

This paper recommended that in addition to taxpayers be given online access to their tax account, this online access will ensure that the taxpayers can check their transactions and balances on real-time basis to assured the accuracy and reliability of the transaction conducted through e-tax service. Taxpayers are unwilling to adopt electronic tax service, thus to attract taxpayers to adopt electronic tax service; there should be time and cost saving, should improve both income of the tax authority and taxpayers, it should free from any type of risk and taxpayers should use the system easily without need of formal learning.

The probit regression model for adoption decision indicates that perceived risk has the probability to decrease adoption for e-tax service, thus the tax authority and government should create secure internet connection and strong password for taxpayers to alleviate risk probabilities. To avoid risk the researcher suggested that the tax authority should provide confirmation once the transactions made through electronic tax system are successfully updated into the taxpayers' tax account. This confirmation can be distributed through email and other social media to the taxpayers' mailboxes. By providing this confirmation, the taxpayers will feel confident that their transactions are accurately and safely transferred to their tax account.

Self-efficiency has a significant effect for the adoption of electronic tax service. The descriptive and econometric model analyses indicate that self-efficient taxpayers have more chance to adopt the than counterparts, thus the tax authority should do on providing successive training to taxpayers to perform the system by themselves without any supporter.

The tax authority should also provide online assistance to help taxpayers who have difficulties in operating the electronic tax service to pay and report their taxes and the tax authority should provide a more comprehensive user manual to new adopters to have general overview on how to use e-tax service. Since the study revealed that small number of electronic tax service user are existed, non-users should know the income difference between users and non-users plus there should know how much cost and time they save as a result of adopting the service. Thus tax authorities and government should work on create awareness to taxpayers about the e-tax service. In the current time electronic tax service is used in Addis Ababa only, the tax authority should create access to other branches to adopt the system. As the e-tax service is effective and productive in the three (west, east and large taxpayers) branches in Addis Ababa, government should expand the service to other branches.

\section{Acknowledgment}

Above all, I would like to thank my Lord Allah for being with me in all aspects of my life.

Secondly, I would like to express my sincere gratitude to all of the study participants who involved in this study for their friendly cooperation and willingness in providing me the relevant information of the study.

\section{Conflict of interest}

The author declared no potential conflicts of interest with respect to the research, authorship, and/or publication of this article.

\section{Funding statement}

This research received no specific grant from any funding agency in the public, commercial, or not-for-profit sectors.

\section{REFERENCE}

Alba, J., \& L. (1997). Interactive Home Shopping: Consumer, Retailer, and Manufacturer Incentives to Participate in Electronic Marketplaces. J. Mark. 61(3). pp. 38-53.

Amin, B., \& Muhammad, M. (2007). An Analysis of mobile banking acceptance by Malaysian customers. Sunway Academic Journal , 1-12.

Amin, H. (2008). Factors affecting the intentions of customers in Malaysia to use mobile phone credit cards. . Management Research News, , 493-503.

Beneke, J., Acton, A., Richardson, D. \& White, F. (2011). E-Service Quality: an investigation of its key dimensions and the discriminatory power in the residential property sector, South Africa

Benk, S., \& Budka, T. (2011). the Acceptance of Tax Office Automation System (VEDOP) By Employees: Factorial Validation of Turkish Adapted Technology Acceptance Model.

Bernama. (2009). IRB Notes 30 Per Cent Increase In E-Filing. Retrieved Mei 1, 2009 from://www.bernama.com/bernama//v3.

Creswell, J. (2003). Research design:Qualitative, quantitative and mixed methods approaches. (2nd, Ed.) Thousand Oaks;CA:SAGE Publications.

Chang, I-Chiu, Li, Yi-Chang, Hung, Wong-Fu \& Hung, H. (2005), 'An empirical study on the impact of quality antecedents on taxpayers' acceptance of Internet tax filing systems', Government Information Quarterly, vol. 22, no. 3, pp 389-410. 
Chau, Y. K.,\& Hu Paul J. H. (2002), investigating healthcare professionals' decisions to accept telemedicine technology: an empirical test of competing theories, Information and Management, Volume 39, pp. 297 311

Chau, Y. K., \& Hu, J. H. (2001), Information technology acceptance by individual professionals: A model comparison approach. Decision Sciences, 32(4), 699-718.

Davis, F. D. (1989). Perceived Usefulness, perceived Ease of use and user acceptance of information technology. 13, pp. pp 318-340.

Davis,FD, Bagozzi,RP.,\&Warshaw, PR. (1989), User Acceptance of Computer Technology: A Comparison of Two Theoretical Models. Manage. Sci. 35(8): 982-1003.

ERCA. (2010). Retrieved from http://www.icfafrica.org.

ERCA. (2013). Retrieved from (http://www.2merkato.com.

ERCA. (2015). Retrieved from https://addisbiz.com.

Gujarati. (2004). Basic Econometrics, fourth edition, TATA McGraw Hill, Companies.

Hoffman,DL. Novak TP \& Chatterjee, P. (1995), Commercial Scenarios for the Web: Opportunities and Challenges. J. Comput.-Mediated Commun. 1(3): 58-62

Hu PJH, Brown SA, Thong JYL, Chan FKY, \& Tam KY (2009), Determinants of Service Quality and Continuance Intention of Online Service: The Case of e-Taxpayers

Hung Shin-Yuan, Chang Chia-Ming\& Yu Ting-Jing (2006), Determinants of user acceptance of e-government services: The case of online tax filing and payment system, Government Information Quarterly, pp 97-122

Hung SY., Chang CM.,\&Yu TJ. (2006). Determinants of User Acceptance of the e-Government Services: The Case of Online Tax Filing and Payment System. Gov. Inf. Q. 23: 97-122.

Hussein, R., Mohamed, N.,Ahlan, Abd R. \& Mahmud, M. (2010)," E-government application: an integrated model on G2C adoption of online tax." Transforming Government: People, Process and Policy Vol. 5 No. 3, 2011 pp. 225-248.

https://en.wikipedia.org. (n.d.). definition of taxpayer.

Ing Long, W., \& Jian-Liang, C. (2005). An extension of Trust and technology acceotance model with TPB in the initial adoption of on-line tax: An empirical study.

Irani, Z., Osman, I.H., Balci, A., Ozkan, S. \&Medeni, T.D. (2008), "Research note toward a reference process model for citizen-oriented evaluation of e-government services", Transforming Government: People, Process and Policy, Vol. 2 No. 4, pp. 297-310.

Jen-Ruei Fu, Cheng-Kiang F., \& Wen-Pin C. (2005) Acceptance of electronic tax filing: A study of taxpayer intentions

Johnson, N. (2009). a survey of benefits and challenges in electronic billing and payment in the Kenya power and lighting company limited, University of Nairobi, Kenya.

Kothari, C. (2004). Research Methodology: Methods and Techniques ( 2 nd ed.). New Dehli: New Age International Publishers Ltd.

Madalla, G. (1983). Limited Dependent and Qualitative Variables in Econometrics. pp. 260-285. Cambridge University Press, United Kingdom. Heckman J (1979) Sample selection bias as a specification error. pp 153161.

Malek, i. N., \& Alireza. (2011). A survey of the impact of the effective factors in adoption and application of information technology in offering electronic taxation services by taxpayers: A case study of the taxpayers.

Moyi, E., \& Ronge, E. (2006). Taxation and tax modernization in Kenya: A diagnosis of performance and options for further reform.

Mugenda, O. M. (2003). Research Methods: Quantitative and Qualitative . Nirobi.

Mukesh, A. (2011). Auditing E-taxation: Issues and Challenges, Pg 35.

Noorbakhsh, M., Akbar, B.,Shahriar,B.,Yeshan,d. \&Ali N. (2015).Electronic Payment of Taxes,.

Pant V., Stiner M.S. \& Wagner W. P. (2004). E-taxation-An introduction to the use of Tax for corporate tax reporting

Peterson RA., Balasubramanian S., Bronnenberg, BJ. (1997), Exploring the implication of the Internet for Consumer Marketing. J. Acad. Mark. Sci. 25 (4): 329-346.

Ramayah, T., \& Aafaqi, B. (2004). Role of self-efficacy in e-library usage among students of a public university in Malaysia. 1, pp39-57.

Scott M, S., \& Albaum, G. An Introduction to Marketing Research. 2010.

Sheidaei \& ShahRukh. (2012). the identification of factors affecting the acceptance of the e- system to receive tax returns using planned behavior theory, case study of the General Authority for tax affairs.

Sunahi, A. (2010). determinants of online tax payment system in Malaysia, volume 1.

Sweeney JC.,Soutar GN., Johnson LW (1999). The Role of Perceived Risk in the Quality-Value Relationship: A Study in a Retail Environment. J. Retailing 75(1): 771-705.

Tella, A., \& Olsina, G. (2014). Predicting users' continuance intention toward e-payment System. 
Teodora, V. (2008). the role of e-government in the rise of administrative efficiency, the technology acceptance model. International Journal of Information Systems \& Social Change .

Torres, L. P., \& Acrete, B. (2005). "Electronic government developments on delivering public services among EU cities", Government Information Quarterly. Vol. 22. No. 2, pp. pp 217-38.

Trauner, V. (2005). Electronic taxation: state and perspectives, series informatics. 21.

Wang, Y. (2002). The adoption of electronic tax filing Systems: An empirical Study. pp 333-352.

Webropol. (2001). Webropol training material a training held.

Woodridge. (2002). Introductory Econometrics: A modern Approach, The MIT Press, Cambridge and London.

Wooldridge, J. (2003). Introductory Econometrics. South-Western: Ohio.

Yunusa, A. (2003). Understanding the Principles and Practice of Taxation in Nigeria.

Zhao, Y., \& Saha, P. (2005). Relationship between online service quality and customer satisfaction: A study in internet banking; the case of Lulea University of Technology Sweden.

\section{Appendixes- Necessary tests of the study}

Appendix 1Test of overall goodness of fit

. Ifit

\section{Probit model for adopter, goodness-of-fit test}

$$
\begin{aligned}
& \text { number of observations }=\quad 208 \\
& \text { number of covariate patterns }=30 \\
& \text { Pearson } \operatorname{chi2}(24)=18.68 \\
& \text { Prob }>\text { chi2 }=0.7690
\end{aligned}
$$

Appendix 2 Test of model adequacy

Probit regression

$\begin{array}{llr}\text { Number of obs } & = & 208 \\ \text { LR chi2(2) } & = & 79.75 \\ \text { Prob chi2 } & = & 0.0000 \\ \text { Pseudo R2 } & = & 0.4383\end{array}$

\begin{tabular}{r|rrrrrr}
\hline adopter & Coef. & Std. Err. & $z$ & P $>|z|$ & [95\% Conf. Interval] \\
\hline - hat & 1.275342 & .2578814 & 4.95 & 0.000 & .7699039 & 1.78078 \\
- hatsq & .156547 & .1085323 & 1.44 & 0.149 & -.0561724 & .3692664 \\
_cons & -.0325292 & .1709743 & -0.19 & 0.849 & -.3676328 & .3025743 \\
\hline
\end{tabular}

Appendix 3Pearsons Contingency coefficient for dummy (discrete) variable - corr pu pr sn se ti $(\mathrm{obs}=208)$

\begin{tabular}{r|rrrrr} 
& pu & pr & sn & se & tI \\
\hline pu & 1.0000 & & & & \\
pr & -0.3488 & 1.0000 & & & \\
sn & -0.2284 & 0.1468 & 1.0000 & & \\
se & 0.2334 & -0.2059 & -0.0224 & 1.0000 & \\
tI & -0.0161 & -0.1596 & 0.0657 & -0.0430 & 1.0000
\end{tabular}


Appendix 4Shapiro-Wilk tests for Normality

- swilk pu pr sn se tl

Shapiro-Wilk w test for normal data

\begin{tabular}{r|ccccc} 
Variable & Obs & W & V & z & Prob>z \\
\hline pu & 208 & 0.99718 & 0.435 & -1.918 & 0.97244 \\
pr & 208 & 0.98997 & 1.548 & 1.007 & 0.15696 \\
sn & 208 & 0.98940 & 1.637 & 1.136 & 0.12806 \\
se & 208 & 0.99860 & 0.217 & -3.528 & 0.99979 \\
tl & 208 & 0.99967 & 0.050 & -6.890 & 1.00000
\end{tabular}

Appendix 5Test of hetroskedasticity of the error term

- hettest

Breusch-Pagan / Cook-Weisberg test for heteroskedasticity

Ho: Constant variance

Variables: fitted values of adopter

$\operatorname{chi2}(1) \quad=\quad 79.66$

Prob $>$ chi2 $=0.0000$

Appendix 6Marginal effects of the probit model for the factors of taxpayers' adoption for e-tax service Marginal effects after probit

$y=\operatorname{Pr}$ (adopter) (predict)

$=.04675043$

\begin{tabular}{|c|c|c|c|c|c|c|c|}
\hline variable & $d y / d x$ & Std. Err. & z & $\mathrm{P}>|\mathrm{z}|$ & $95 \%$ & C.I. & $\mathrm{X}$ \\
\hline $\mathrm{pu} *$ & .1747499 & .04448 & 3.93 & 0.000 & .087561 & .261939 & .413462 \\
\hline$p r^{*}$ & -.1566222 & .05577 & -2.81 & 0.005 & -.265925 & -.04732 & .721154 \\
\hline $\mathrm{sn} *$ & .0102213 & .02746 & 0.37 & 0.710 & -.043593 & .064035 & .725962 \\
\hline $\mathrm{se}^{*}$ & .0973823 & .04249 & 2.29 & 0.022 & .014101 & .180664 & .596154 \\
\hline$t l^{*}$ & .0736737 & .0341 & 2.16 & 0.031 & .006845 & .140503 & .509615 \\
\hline
\end{tabular}

$\left({ }^{*}\right) d y / d x$ is for discrete change of dummy variable from 0 to 1 